\title{
RT-PCR as a tool for systematic transcriptional analysis of large regions of the Bacillus subtilis genome
}

\author{
Alicia Hernández, Angélica Figueroa, Luis A. Rivas, Víctor Parro \\ and Rafael P. Mellado
}

Author for correspondence: Rafael P. Mellado. Tel: +34 91 5854547. Fax: +34 915854506.

e-mail: rpmellado@cnb.uam.es

Centro Nacional de Biotecnología (CSIC) Campus de Universidad Autónoma, Cantoblanco, 28049 Madrid, Spain

\author{
Transcriptional analysis of five different regions of the Bacillus subtilis 168 \\ genome, comprising a total of $175 \mathrm{~kb}$ encoding newly identified genes, was \\ carried out using the RT-PCR technique as part of the functional analysis of the \\ whole genome of this bacterium. Amplification of mRNA fragments allowed \\ the detection of both highly and poorly transcribed genes covering $81 \%$ of \\ putative ORFs, and also the monitoring of variations in the expression level \\ among genes differentially expressed during particular bacterial growth \\ phases.
}

Keywords: Bacillus subtilis, transcription, new genes

\section{INTRODUCTION}

Studies of the expression of large genomic regions in bacteria are technically difficult since until recently simultaneous analysis of coordinated expression was only possible for a limited subset of genes. Most of the currently available methodology for studying differential expression of genes is applicable only to eukaryotic poly $(\mathrm{A})$-tailed mRNA; the absence of polyadenylation in prokaryotic mRNA does not help in bacterial transcriptional analysis. Only $4-5 \%$ of the total bacterial RNA preparation is mRNA, which adds a further element of considerable difficulty in detecting transcription of bacterial genes, particularly of those that are poorly expressed or that have highly unstable messengers.

A rRNA subtraction approach has been used to identify differentially expressed bacterial genes (Plum \& ClarkCurtiss, 1994) but, after removal of rRNA, it is difficult to get clean mRNA preparations without selective loss of mRNA. Methods relying on differential hybridization to overlap moderately large clones of the bacterial genome (Chuang et al., 1993) require subcloning followed by sequencing of the relevant genes. Monitoring expression of a large number of genes in eukaryotes has been possible by using DNA arrays or oligonucleotide microarrays (Pease et al., 1994; Lockhart et al., 1996; Wodicka et al., 1997). Hybridization of labelled cDNA or mRNA to the high-density probe microarrays allowed the analysis of expression of many genes in a single hybridization experiment. Due to the high back- ground that a probe of labelled total RNA would give, DNA or oligonucleotide microarray technology may not be applicable for bacterial transcriptional analysis. Nevertheless, the method has been adapted to monitor gene expression in Streptococcus pneumoniae (de Sazieu et al., 1997) with promising results, but it requires hybridization to probes labelled either by radioactivity or otherwise. Here, we demonstrate the applicability of specific amplification of mRNA fragments; the mRNA complementary strand is synthesized in the presence of reverse transcriptase followed by several rounds of amplification by PCR using appropriate sets of oligonucleotides. The method needs as little as $50 \mathrm{ng}$ total RNA, does not require the use of labelled probes in hybridization experiments and allows monitoring of the presence of different levels of RNA.

\section{METHODS}

Standard media and DNA manipulations. Bacillus subtilis 168 $(\operatorname{trpC2})$ was the strain used in the experiments and was provided by C. Anagnostopoulos (INRA, Jouy-en-Josas, France). The procedures for the growth of B. subtilis and DNA manipulation were as described by Harwood \& Cutting (1990). DNA was isolated from B. subtilis cultures grown at $37^{\circ} \mathrm{C}$ in minimal medium, nutrient broth and sporulation medium as described by Harwood \& Cutting (1990) and Schaeffer et al. (1965). MM contains Spizizen minimal salts (Anagnostopoulos \& Spizizen, 1961) supplemented with $0.4 \%$ $(\mathrm{w} / \mathrm{v})$ glucose, $0 \cdot 2 \%(\mathrm{w} / \mathrm{v})$ L-glutamine, $50 \mathrm{~g} \mathrm{~L}$-tryptophan $\mathrm{I}^{-1}$ and trace elements (Harwood \& Cutting, 1990) containing $4 \mathrm{mg} \mathrm{FeCl} \mathrm{I}^{-1}$ and $0 \cdot 2 \mu \mathrm{g} \mathrm{MnSO}_{4} \mathrm{l}^{-1}$ instead of $\mathrm{FeCl}_{2}$ and $\mathrm{MnCl}_{2}$, respectively, adjusted to $\mathrm{pH} 7 \cdot 0$. NB contains $8 \mathrm{~g}$ 
Table 1. Primers used for RT-PCR

f, Forward primer; r, reverse primer.

\begin{tabular}{|c|c|c|c|c|c|c|c|}
\hline \multicolumn{4}{|c|}{$936 \cdot 6-976 \cdot 6 \mathrm{~kb}$} & \multicolumn{2}{|c|}{$1265 \cdot 4-1280 \mathrm{~kb}$} & \multicolumn{2}{|c|}{$2744-2767 \mathrm{~kb}$} \\
\hline $\begin{array}{l}\text { Gene/ } \\
\text { primer }\end{array}$ & Coordinates & $\begin{array}{l}\text { Gene/ } \\
\text { primer }\end{array}$ & Coordinates & $\begin{array}{l}\text { Gene/ } \\
\text { primer }\end{array}$ & Coordinates & $\begin{array}{l}\text { Gene/ } \\
\text { primer }\end{array}$ & Coordinates \\
\hline$y f h R-f$ & 936859-936883 & $y g b A-f^{*}$ & $962033-962057$ & $y j c P-f$ & $1266242-1266261$ & aapA-f & 2766389-2766413 \\
\hline$y f h R-r$ & $937136-937112$ & $y g b A-r$ & $962321-962297$ & $y j c P-r$ & $1266478-1266457$ & aapA-r & $2766762-2766786$ \\
\hline ygab-f & 937749-937773 & ygaM-f & $962915-962939$ & $y j c Q-f$ & $1266645-1266666$ & $y r a A-f$ & $2756759-2756783$ \\
\hline ygaB-r & $938090-938066$ & $y g a M-r$ & $963208-963184$ & $y j c Q-r$ & $1266854-1266832$ & $y r a A-r$ & $2757223-2757199$ \\
\hline$y g a C-f$ & $938237-938261$ & $y g c A-f$ & $962915-962939$ & $y j c R-f$ & $1267147-1267168$ & $a d h A-f$ & 2755599-2755622 \\
\hline$y g a C-r$ & 938551-938527 & $y g c A-r$ & $964663-964639$ & $y j c R-r$ & $1267461-1267430$ & $a d h A-r$ & $2756062-2756049$ \\
\hline$y g a D-f$ & $939486-939510$ & $y g a N-f$ & $964938-964962$ & $y j d A-f$ & $1268505-1268526$ & yraB-f & $2754991-2754968$ \\
\hline$y g a D-r$ & $939986-939962$ & $y g a N-r$ & $965199-965175$ & $y j d A-r$ & $1268896-1268873$ & yraB- $r$ & $2754724-2754703$ \\
\hline$y g a E-f$ & $941361-941337$ & $y h z A-f^{*}$ & $965418-965442$ & $y j d B-f$ & $1269464-1269446$ & yraC- $r$ & $2754674-2754650$ \\
\hline$y g a E-r$ & $941020-941044$ & $y b z A-r$ & $965684-965660$ & $y j d B-r$ & $1269295-1269314$ & yraC-f* & $2754410-2754434$ \\
\hline$y g a F-f$ & $943396-943420$ & $y g a \mathrm{O}-f^{*}$ & $966178-966154$ & $y j d C-f *$ & $1270862-1270883$ & $y r a D-r$ & $2754332-2754308$ \\
\hline$y g a F-r$ & $943635-943611$ & $y g a \mathrm{O}-r$ & $965708-965732$ & $y j d C-r$ & $1271210-1271189$ & yraD-f & 2754169-2754193 \\
\hline$y g a G-f$ & $944091-944115$ & $y b b A-f$ & $967753-967777$ & $y j d D-f$ & $1272698-1272725$ & $a d h B-f$ & $2752832-2752855$ \\
\hline$y g a G-r$ & $944338-944314$ & $y h b A-r$ & $968103-968079$ & $y j d D-r$ & $1272994-1272984$ & $a d h B-r$ & $2753277-2753254$ \\
\hline ygaH-f & $944671-944695$ & $y h z B-f^{*}$ & $967361-967337$ & $y j d E-f$ & $1274574-1274600$ & $y r a E-f$ & $2754039-2754015$ \\
\hline$y g a H-r$ & $945000-944976$ & $y h z B-r$ & $966741-966765$ & $y j d E-r$ & $1274857-1274837$ & $y r a E-r$ & $2753780-2753803$ \\
\hline$y g x A-f$ & $945302-945326$ & $y h b B-f$ & $969035-969059$ & $y j d F-f$ & $1275390-1275408$ & yraF-f & $2752603-2752581$ \\
\hline$y g x A-r$ & $945620-945596$ & $y b b B-r$ & $969308-969284$ & $y j d F-r$ & $1275658-1275640$ & yraF-r & $2752430-2752451$ \\
\hline$y g a I-f$ & $953655-953631$ & $\operatorname{csp} R-f^{*}$ & $969644-969668$ & $y j d G-f$ & $1276216-1276192$ & yraG-f & $2752187-2752163$ \\
\hline ygaI-r & $952882-952906$ & $\operatorname{cspR}-r$ & $970123-970099$ & $y j d G-r$ & $1275929-1275952$ & $y r a G-r$ & $2752030-2752054$ \\
\hline$y g z A-f^{*}$ & $953797-953821$ & $y b b D-f$ & 970349-970373 & $y j d H-f$ & $1276860-1276836$ & yraH-f & $2751717-2751693$ \\
\hline$y g z A-r$ & $953997-953973$ & $y h b D-r$ & $970654-970630$ & $y j d H-r$ & $1276634-1276656$ & yraH-r & $2751548-2751566$ \\
\hline$y g a J-f$ & $954640-954642$ & $y h b E-f$ & $971084-971108$ & $y j d I-f$ & $1277251-1277272$ & yral-f & 2750949-2750925 \\
\hline$y g a J-r$ & $954920-954896$ & $y b b E-r$ & 971379-971355 & $y j d I-r$ & $1277534-1277513$ & yraI-r & $2750630-2750616$ \\
\hline thiA-f & $955403-955427$ & $y h b F-f^{*}$ & $971760-971784$ & $y j d J-f$ & $1278267-1278240$ & yraJ-f & $2750421-2750399$ \\
\hline thiA-r & $957172-957148$ & $y h b F-r$ & $972170-972146$ & $y j d J-r$ & $1278144-1278164$ & yraJ-r & $2750260-2750240$ \\
\hline$y g a K-f$ & $957601-957625$ & $y b b H-f$ & $975004-975028$ & $y j d K-f^{*}$ & $1279755-1279729$ & yraK-f & $2748987-2748965$ \\
\hline ygaK-r $r$ & $958060-958036$ & $y b b H-r$ & 975313-975289 & $y j d K-r$ & $1279259-1279284$ & yraK-r & $2749282-2749260$ \\
\hline$y g a L-f$ & $961165-961189$ & & & & & $y r a L-f$ & $2748965-2748987$ \\
\hline \multirow[t]{9}{*}{$y g a L-r$} & $961470-961446$ & & & & & $y r a L-r$ & $2749260-2749282$ \\
\hline & & & & & & $c s n-f$ & $2747875-2747852$ \\
\hline & & & & & & $c s n-r$ & $2747596-2747618$ \\
\hline & & & & & & yraM-f & $2746819-2746796$ \\
\hline & & & & & & yraM-r & $2746422-2746401$ \\
\hline & & & & & & yraN-f & $2745259-2745282$ \\
\hline & & & & & & yraN-r & $2745629-2745651$ \\
\hline & & & & & & yraO-f & $2744476-2744498$ \\
\hline & & & & & & yraO-r & $2744092-2744114$ \\
\hline
\end{tabular}

Difco Bacto Nutrient Broth $\mathrm{l}^{-1}$ supplemented with $0 \cdot 25 \mathrm{~g}$ $\mathrm{MgSO}_{4} .7 \mathrm{H}_{2} \mathrm{O} \mathrm{l}^{-1}, 1 \mathrm{~g} \mathrm{KCl} \mathrm{l}^{-1}, 0 \cdot 1 \mathrm{mM} \mathrm{MnCl}, 1 \mu \mathrm{M} \mathrm{FeSO}_{4}$ and $1 \mathrm{mM} \mathrm{CaCl}$, adjusted to $\mathrm{pH} 7 \cdot 1$. For induction of the ara operon, B. subtilis cells were grown in minimal $\mathrm{C}$ medium (Pascal et al., 1971) supplemented with $1 \%(\mathrm{w} / \mathrm{v})$ casein hydrolysate, and L-arabinose or glucose was added to the cultures as carbon sources at a final concentration of $0.4 \%$ (w/v).

Transcriptional analysis. Aliquots from the different cultures were lysed (Mellado et al., 1981) and total RNA was extracted at the times indicated in the Results and Discussion section as described by Kedzierski \& Porter (1991). Total RNA from sporulating cells was prepared in the same manner but a grinding step with glass beads ( $2 \mathrm{~mm}$ diameter) was used to break the sporulating cells before lysis. When necessary, RNA preparations were rendered DNA-free by incubation with DNase-RNase free (Promega), following the supplier's manual. RT-PCR analysis was carried out by incubating the amounts of total RNA preparations indicated in the Results and Discussion section first with AMV reverse transcriptase, and then with Thermus flavus DNA polymerase. The Promega Access RT-PCR system kit containing both enzymes was used, following the supplier's manual. RT-PCR reactions were carried out in a final volume of $100 \mu \mathrm{l}$ using the oligonucleotides indicated in Table 1 as primers. RT-PCR reactions were carried out in automated thermocyclers (PTC-100, MJ Research) by incubation at $48^{\circ} \mathrm{C}$ for $45 \mathrm{~min}$ followed by $2 \mathrm{~min}$ heating at $95^{\circ} \mathrm{C}$. Amplifications were carried out by 40 cycles of incubation at $94^{\circ} \mathrm{C}(0.5 \mathrm{~min}), 60^{\circ} \mathrm{C}(1 \mathrm{~min})$ and $68^{\circ} \mathrm{C}$ ( $2 \mathrm{~min}$ ), with a final extension step of incubation at $68^{\circ} \mathrm{C}$ for $7 \mathrm{~min}$. The amplified DNA fragments were analysed by $1.5 \%$ $(\mathrm{w} / \mathrm{v})$ agarose gel electrophoresis; up to 108 samples were run at the same time in a Scie-Plas electrophoresis unit.

\section{RESULTS AND DISCUSSION}

\section{Transcriptional analysis by RT-PCR}

Five different regions of the $B$. subtilis genome, 936.6$976.6 \mathrm{~kb}, \quad 1265.4-1280 \mathrm{~kb}, \quad 2744-2767 \mathrm{~kb}, \quad 2854.4-$ $2964.4 \mathrm{~kb}$ and $3384-3430 \mathrm{~kb}$ (numbering according to Kunst et al., 1997), were chosen as large genomic regions to conduct simultaneous trancriptional analysis of newly identified genes. The five regions encompass a total of $175 \mathrm{~kb}$ of new sequence and comprise up to 181 ORFs. To assess if all the putative new genes deduced from the sequencing analysis of the bacterial genome did correspond to functional genes, we needed to develop methods to allow fast, easy and sensitive global trans- 
Transcriptional analysis of the B. subtilis genome

Table 1 (cont.)

\begin{tabular}{|c|c|c|c|c|c|c|c|c|c|}
\hline \multicolumn{6}{|c|}{$2854 \cdot 4-2964 \cdot 4 \mathrm{~kb}$} & \multicolumn{4}{|c|}{$3384-3430 \mathrm{~kb}$} \\
\hline $\begin{array}{l}\text { Gene/ } \\
\text { primer }\end{array}$ & Coordinates & $\begin{array}{l}\text { Gene/ } \\
\text { primer }\end{array}$ & Coordinates & $\begin{array}{l}\text { Gene/ } \\
\text { primer }\end{array}$ & Coordinates & $\begin{array}{l}\text { Gene/ } \\
\text { primer }\end{array}$ & Coordinates & $\begin{array}{l}\text { Gene/ } \\
\text { primer }\end{array}$ & Coordinates \\
\hline$d n a B-f$ & 2964133-2964109 & $y \operatorname{shB}-r$ & $2924374-2924398$ & $i l v N-f$ & $2894342-2894618$ & $y v g O-f$ & $3426885-3426909$ & $y v r G-f^{*}$ & $3407253-3407235$ \\
\hline$d n a B-r$ & $2963768-2963743$ & $y \operatorname{sh} B-f$ & 2924594-2924571 & $i l v N-r$ & 2893893-2893917 & $y v g O-r$ & $3427175-3427151$ & $y v r G-r$ & $3406826-3406844$ \\
\hline$y t x B-f$ & 2962020-2961996 & $y$ slA-f & 2907791-2907815 & $i l v C-f$ & 2893694-2893670 & $y v s A-f$ & $3427062-3427044$ & $y v r E-f$ & $3405402-3405390$ \\
\hline$y t x B-r$ & $2961746-2951722$ & $y s l A-r$ & 2908089-2908066 & $i l v C-r$ & $2892881-2892905$ & $y v s A-r$ & $3426915-3426933$ & $y v r E-r$ & $3405079-3405097$ \\
\hline$y t x C-f$ & $2960366-2960343$ & $y \operatorname{shC}-f^{*}$ & 2923511-2923491 & $\operatorname{leu} A-f$ & $2892390-2892412$ & $y v g N-f^{*}$ & $3426546-3426522$ & $y v r D-r$ & $3404596-3404572$ \\
\hline$y t x C-r$ & 2960054-2960078 & $y s h C-r$ & 2923009-2923032 & leuA-r & 2891897-2891919 & $y v g N-r$ & $3425956-3425981$ & $y v r D-f$ & $3404047-3404071$ \\
\hline$y s a A-f$ & $2957721-2957739$ & $y s h D-f$ & $2921450-2921428$ & leuB- $f$ & $2890827-2890803$ & $y v g M-r$ & $3425730-3425706$ & $y v r C-f$ & $3403353-3403335$ \\
\hline$y s a A-r$ & $2958065-2958047$ & $y s h D-r$ & 2920989-2921011 & $\operatorname{leuB-r}$ & $2890396-2890420$ & $y v g M-f$ & $3425400-3425424$ & $y v r C-r$ & $3403052-3403070$ \\
\hline lytS-f & $2957254-2957236$ & $y s h E-f$ & 2919943-2919919 & leuC-f & 2889609-2889585 & $y v g L-r$ & $3424916-3424892$ & $y v r B-f^{*}$ & $3402423-3402399$ \\
\hline lytS-r & $2956957-2956975$ & $y s h E-r$ & $2919752-2919776$ & leuC-r & 2889154-2889177 & $y v g L-f$ & $3424403-3424427$ & $y v r B-r$ & $3402000-3402024$ \\
\hline lyt $T-f$ & $2955537-2955519$ & $l c f A-f$ & $2918895-2918873$ & leuD-f & $2888537-2888513$ & $y v g K-f$ & $3423931-3423913$ & $y v r A-f^{*}$ & $3401092-3401068$ \\
\hline lyt $T-r$ & $2955092-2955110$ & $l c f A-r$ & $2918354-2918376$ & leuD-r & $2888225-2888221$ & $y v g K-r$ & $3423605-3423623$ & $y v r A-r$ & $3400706-3400730$ \\
\hline$y s b A-f$ & $2954783-2954759$ & $y s i A-f$ & $2917607-2917584$ & $y s o A-f$ & $2887542-2887522$ & $y v g J-f *$ & $3421871-3421889$ & $y v q K-f$ & $3399985-3399967$ \\
\hline$y s b A-r$ & $2954382-2954406$ & $y s i A-r$ & $2917322-2917345$ & $y s o A-r$ & $2887190-2887212$ & $y v g J-r$ & $3422113-3422095$ & $y v q K-r$ & $3399808-3399826$ \\
\hline$y s b B-f$ & $2953997-2953975$ & $y s i B-r$ & $2916441-2916465$ & $y s o C-f$ & $2884247-2884221$ & $y v s G-f$ & $3420935-3420917$ & $y v q J-f$ & $3399265-3399247$ \\
\hline$y s b B-r$ & $2953656-2953678$ & $y s i B-f$ & 2916759-2916735 & $y s o C-r$ & $2883999-2884023$ & $y v s G-r$ & $3421150-3421168$ & $y v q J-r$ & 3398874-3398892 \\
\hline$y s c A-f$ & $2952604-2952627$ & etf $B-f$ & $2916145-2916121$ & $\operatorname{lon} A-f$ & $2881007-2880983$ & $y v s H-f$ & $3419903-3419885$ & $y v q I-f$ & $3397962-3397944$ \\
\hline$y s c A-r$ & $2952850-2952831$ & $e t f B-r$ & $2915728-2915752$ & $\operatorname{lon} A-r$ & $2880687-2880711$ & $y v s H-r$ & $3419673-3419691$ & $y v q I-r$ & $3397732-3397750$ \\
\hline$y s c B-r$ & $2953390-2953368$ & etf $A-f$ & $2915143-2915121$ & $y s x C-f$ & $2879425-2879401$ & $f b u D-r$ & $3418408-3418432$ & $y v q H-f$ & $3397452-3397434$ \\
\hline$y s c B-f$ & 2953081-2953104 & etfA- $r$ & 2914791-2914812 & $y s x C-r$ & $2879048-2879072$ & fbuD-f & $3417832-3417858$ & $y v q H-r$ & $3397120-3397138$ \\
\hline$r p m I-f$ & $2951981-2951957$ & asd-f & $2913628-2913610$ & $y s x D-r$ & $2878759-2878737$ & fbuB-f* & $3417288-3417312$ & $y v q G-f$ & $3396539-3396521$ \\
\hline$r p m I-r$ & $2951726-2951749$ & asd-r & 2913254-2913271 & $y s x D-f$ & $2878483-2878507$ & $f b u B-r$ & $3416497-3416521$ & $y v q G-r$ & $3396198-3396216$ \\
\hline$r p l T-f$ & $2951586-2951563$ & $y s l B-f$ & $2908202-2908225$ & hemA-f & $2878063-2878039$ & $f h u G-f$ & $3416263-3416239$ & $y v q F-f$ & $3395706-3395688$ \\
\hline$r p l T-r$ & $2951388-2951368$ & $y s l B-r$ & 2908419-2908396 & hemA-r & $2877151-2877175$ & $f b u G-r$ & $3415335-3415359$ & $y v q F-r$ & $3395368-3395386$ \\
\hline$y s d A-r$ & $2951057-2951077$ & $s d h C-f$ & $2907730-2907706$ & hemX-f & $2876774-2876751$ & $f b u C-f *$ & $3415220-3415196$ & $y v q E-f$ & $3395099-3395081$ \\
\hline$y s d A-f$ & $2951216-2951193$ & $s d h C-r$ & $2907448-2907473$ & hemX-r & $2876113-2876137$ & $f b u C-r$ & $3414567-3414591$ & $y v q E-r$ & $3394903-3394921$ \\
\hline$y s d B-r$ & $2950936-2950912$ & $s d h A-f$ & $2906450-2906426$ & hem $\mathrm{C}-f^{4}$ & $2875974-2875951$ & $y v r P-f^{*}$ & $3414175-3414157$ & $y v q D-f$ & $3394235-3394253$ \\
\hline$y s d B-f$ & $2950656-2950677$ & $s h d A-r$ & $2906072-2906096$ & hemC-r & $2875129-2875153$ & $y v r P-r$ & $3413817-3413835$ & $y v q D-r$ & $3394537-3394519$ \\
\hline$y s d C-f$ & 2949951-2949933 & $s d h B-f$ & 2905250-2905226 & hemD-f* & $2875036-2875012$ & $y v r O-f$ & $3413080-3413062$ & $y v q C-f$ & $3394038-3394020$ \\
\hline$y s d C-r$ & 2949631-2949649 & $s d h B-r$ & $2904888-2904912$ & hemD-r & $2874279-2874304$ & yvrO-r & $3412837-3412855$ & $y v q C-r$ & $3393829-3393811$ \\
\hline$a b n A-f$ & $2948812-2948795$ & $y s m A-f$ & $2904528-2904505$ & hemB-f* & $2874094-2874069$ & $y v r N-f$ & $3412419-3412401$ & gerAC-r & $3393446-3393422$ \\
\hline$a b n A-r$ & 2948494-2948512 & $y s m A-r$ & $2904237-2904261$ & hemB-r & $2873587-2873611$ & $y v r N-r$ & $3412223-3412241$ & ger $A C-f$ & $3392441-3392465$ \\
\hline $\operatorname{araL}-f$ & 2944016-2943998 & gerE-f & 2904034-2904013 & hemL-f & $2872982-2872957$ & $y v r M-f$ & $3411890-3411872$ & ger $A B-r$ & $3392348-3392324$ \\
\hline araL-r & $2943532-2943550$ & gerE- $r$ & $2903825-2903849$ & hemL-r & $2872376-2872399$ & $y v r M-r$ & $3411699-3411717$ & ger $A B-f^{*}$ & $3391363-3391387$ \\
\hline$a b f A-f$ & 2938101-2938118 & $y s m B-f$ & 2903469-2903445 & spoVID-f & $2871220-2871196$ & $y v r L-f^{*}$ & $3411089-3411065$ & gerAA-r & $3391047-3391024$ \\
\hline$a b f A-r$ & $2938425-2938407$ & $y s m B-r$ & $2903211-2903235$ & $s p o V I D-r$ & $2870898-2870922$ & $y v r L-r$ & $3410873-3410897$ & $\operatorname{ger} A A-f$ & $3390035-3390058$ \\
\hline $\operatorname{cst} A-f$ & $2936841-2936823$ & race-f & $2902930-2902954$ & $y s x E-f$ & $2869868-2869845$ & $y v r K-f$ & $3409810-3409828$ & $y u x N-r$ & $3387834-3387810$ \\
\hline $\operatorname{cst} A-r$ & 2936391-2936409 & $r a c E-r$ & $2902641-2902664$ & $y s x E-r$ & $2869529-2869552$ & $y v r K-r$ & $3410204-3410186$ & $y u x N-f$ & $3387490-3387515$ \\
\hline$y s f A-r$ & $2930958-2930935$ & $r p h-f$ & $2900815-2900791$ & spollB-f & $2863798-2863174$ & $y v r I-f$ & $3409021-3409003$ & $y v q B-f$ & $3386039-3386021$ \\
\hline$y s f A-f *$ & $2930827-2930851$ & $r p h-r$ & $2900546-2900569$ & spoIIB-r & $2862791-2862815$ & $y v r I-r$ & $3408766-3408784$ & $y v q B-r$ & $3385597-3385615$ \\
\hline$y s f B-r$ & $2931835-2931813$ & $y \sin A-r$ & $2899771-2899795$ & $m a f-f$ & $2862238-2862214$ & $y v r H-f *$ & $3408426-3408408$ & $y v q A-f$ & $3384930-3384948$ \\
\hline$y s f B-f$ & $2931429-2931451$ & $y \sin A-f$ & 2899996-2899972 & $m a f-r$ & $2861937-2861961$ & yvrH-r & $3407976-3407994$ & $y v q A-r$ & $3385150-3385132$ \\
\hline$y s f C-r$ & $2933117-2933093$ & $y \sin B-f$ & 2899529-2899505 & $y s x A-f$ & $2861650-2861626$ & & & & \\
\hline$y s f C-f$ & $2932778-2932802$ & $y s n B-r$ & $2899215-2899239$ & $y s x A-r$ & $2861334-2861358$ & & & & \\
\hline$y s f D-r$ & $2934575-2934553$ & $y s n F-r$ & $2898837-2898816$ & $y s x B-f$ & $2854758-2854736$ & & & & \\
\hline$y s f D-f$ & $2934181-2934203$ & $y \operatorname{sif}-f$ & $2898557-2898582$ & $y s \times B-r$ & $2854459-2854482$ & & & & \\
\hline$y s g A-f$ & $2930576-2930552$ & $y s n E-r$ & $2897745-2897722$ & $r p l U-f$ & $2854709-2854688$ & & & & \\
\hline$y s g A-r$ & 2930440-2930464 & $y s n E-f$ & $2897475-2897496$ & $r p l U-r$ & $2854503-2854524$ & & & & \\
\hline$y s g B-f$ & $2925738-2925717$ & $y s n D-r$ & $2897167-2897143$ & $r p m A-f$ & $2854364-2854341$ & & & & \\
\hline$y s g B-r$ & $2925412-2925434$ & $y s n D-f$ & $2896902-2896926$ & $r p m A-r$ & $2854218-2854242$ & & & & \\
\hline$y \operatorname{sh} A-f$ & $2925011-2924987$ & ilvB-f & $2895670-2895626$ & & & & & & \\
\hline$y \operatorname{sh} A-r$ & $2924810-2924835$ & $i l v B-r$ & 2894859-2894882 & & & & & & \\
\hline
\end{tabular}

* Transcripts not detected by RT-PCR.

criptional analysis. Previous experiments carried out in our laboratory (A. Hernández, V. Parro \& R. P. Mellado, unpublished) demonstrated that RT-PCR analysis permitted detection of transcription of almost twice as many genes as Northern blot analysis; we therefore explored the possible use of RT-PCR for global transcriptional detection and monitoring of gene expression.

As a way to scale up the RT-PCR reaction, amplification of total RNA preparations with different combinations of primer oligonucleotide pairs was assayed. The oligonucleotide pairs lytT-f/lytT-r, lytS-f/lytS-r and
yslB-f/yslB-r (Table 1), corresponding to genes $l y t T$, lyt $S$ and $y s t B$, respectively, were used as primers for RTPCR reactions. The RT-PCRs were carried out in the presence of $500 \mathrm{ng}$ total RNA, either with each pair of primers individually, or with combinations of two or three pairs. A reaction without reverse transcriptase was carried out as a negative control in all cases to ensure that the resulting DNA fragment was not due to amplification of contaminant DNA (not shown). The results proved that combined RT-PCRs for more than one gene in the same reaction resulted in competition for the enzyme with subsequent loss of the corresponding bands. Since $l y t S$ and $l y t T$ may form a potential two- 
gene operon, as deduced from the genome sequencing data (Kunst et al., 1997), the results obtained also illustrate that different pairs of primers for the same transcript could also compete in the combined RT-PCR analysis.

To overcome these difficulties, RT-PCR analysis for individual genes was performed. Fig. 1 shows representative results obtained when putative transcripts for some of the newly found genes in the five different regions of the $B$. subtilis genome were amplified by RTPCR using as a template total RNA isolated from bacterial cultures grown in minimal medium to midexponential phase. All the products obtained were of the expected size and the absence of product in the reactions without RT demonstrates that the bands observed with reverse transcriptase derived from RNA and not from possible contaminant DNA. Most of the genes in all chromosomal regions tested had transcripts which were amplified by RT-PCR when $500 \mathrm{ng}$ total RNA were used in the reaction (as in Fig. 1); increasing the amount of RNA template to $1 \mu \mathrm{g}$ or adding amplification cycles to the reaction did not alter the results (not shown). Genes that did not have RT-PCR-detectable transcripts are shown with an asterisk in Table 1 and amounted to only $18.7 \%$ of the genes tested.

\section{Monitoring of differential gene expression}

We also tested whether the RT-PCR technique could be used to distinguish individual genes that are differentially expressed depending on environmental and/or physiological conditions. The presence of the spoVID transcript was monitored by RT-PCR amplification using $500 \mathrm{ng}$ total RNA preparations from bacteria induced to sporulate by nutrient exhaustion in Schaeffer's medium (Harwood \& Cutting, 1990) in the presence of the appropriate pair of primers (Table 1). Expression of spoVID is known to peak at about the second hour of sporulation and continue throughout spore development (Beall et al., 1993). The results of these experiments are shown in Fig. 2(a). The gene is expressed more abundantly during sporulation than in exponential phases of growth; the different amount of amplified material after the RT-PCR reaction in each case reflected the expected difference in the relative expression level (Beall et al., 1993) (the transcription detected before $T_{2}$ probably reflects the natural asynchrony of the culture), clearly showing that RTPCR amplification can also be of use to distinguish between different levels of gene expression. Transcription from the ara operon is not detected when bacterial cells are grown in the absence of arabinose. When cells were grown in the presence of arabinose, the operon became induced (Sá-Nogueira \& Ramos, 1997) and transcription from two genes of the operon $(a b f A$ and araL) was clearly detected by RT-PCR (Fig. 2b). These results indicate that some of the silent ORFs in the $B$. subtilis genome might not be expressed unless properly induced, as is the case with the ara operon, and that RTPCR could be used to detect differential transcription of genes.
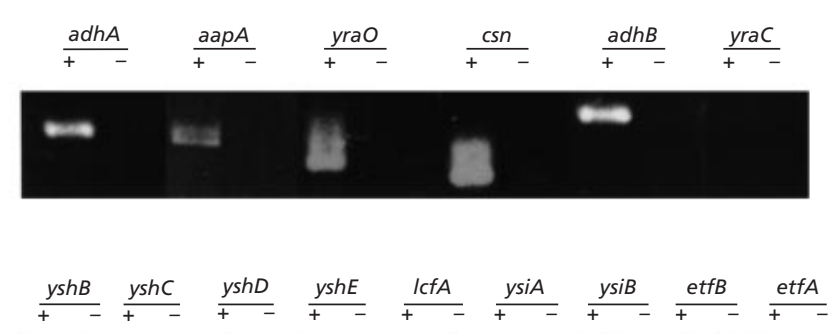

(b)

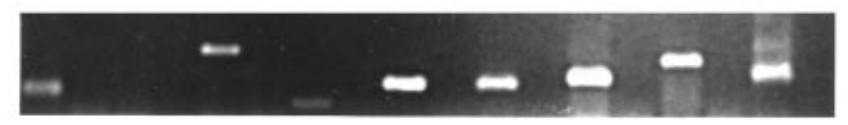

(c)
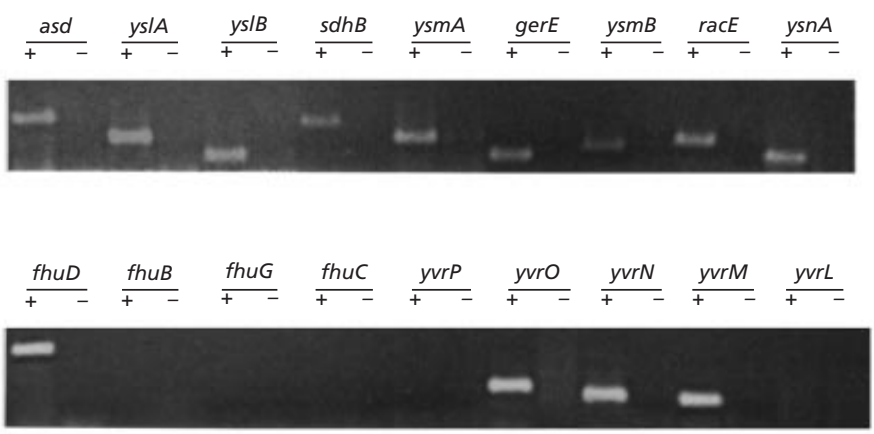

$\frac{y g a O}{+-} \frac{y h b A}{+-} \frac{y h z B}{+-} \frac{y h b B}{+-} \frac{c s p R}{+-} \frac{y h b D}{+-} \frac{y h b E}{+} \frac{y h b F}{+} \frac{y h b H}{+}$

(e)

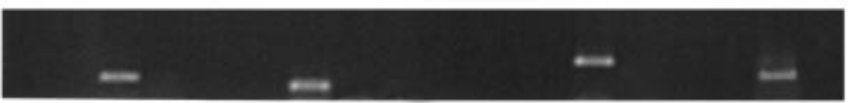

(f)

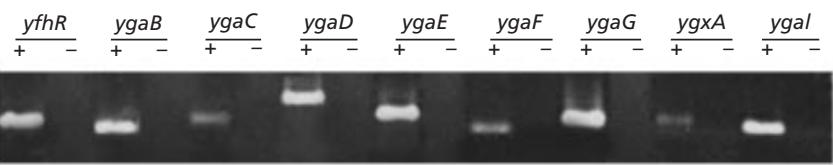

(g)

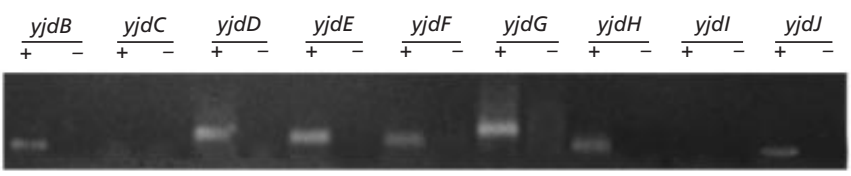

Fig. 1. RT-PCR analysis for individual genes. Reactions were carried out using the corresponding pairs of oligonucleotide primers for the indicated genes. + and - indicate lanes where the reverse trancriptase was present or absent in the reaction, respectively. Total RNA was from cells grown to midexponential phase in minimal medium. (a) Genes from 2744 to $2767 \mathrm{~kb},(\mathrm{~b}, \mathrm{c})$ genes from 2854.4 to $2964.4 \mathrm{~kb}$, (d) genes from 3384 to $3430 \mathrm{~kb}$, (e, f) genes from 936.6 to $976.6 \mathrm{~kb}$, (g) genes from 1265.4 to $1280 \mathrm{~kb}$. Sizes of the amplified fragments ranged between $123 \mathrm{bp}(y j d J)$ and $601 \mathrm{bp}(\mathrm{adhB})$.

\section{RT-PCR sensitivity}

To monitor the sensitivity of the RT-PCR reaction for the detection of transcripts of poorly expressed genes versus those with a higher expression, serial dilutions of 

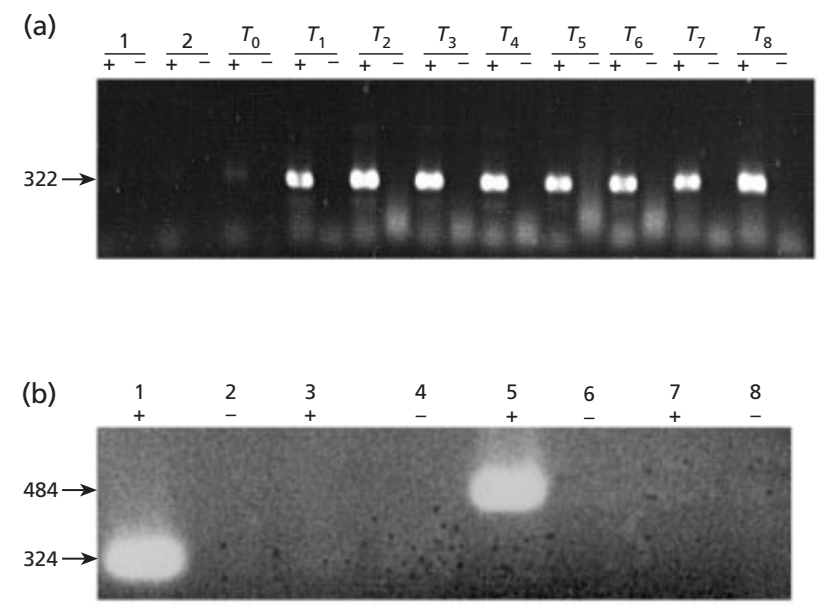

Fig. 2. Differential gene expression. Reactions were carried out using the corresponding pairs of oligonucleotide primers for spoVID (a) or abfA and araL (b). + and - indicate the lanes where reverse trancriptase was present or absent in the reaction, respectively. (a) Total RNA from cells growing in sporulation medium at exponential (lane 1), late exponential (lane 2) and sporulation (lanes $T_{0}-T_{8}$ ) phases. (b) Total RNA from cells grown in the presence (lanes 1, 2, 5 and 6) or absence (lanes 3, 4, 7 and 8) of arabinose was used as a template for the reactions carried out using the abfA pair of primers (lanes 1-4) or the araL pair of primers (lanes 5-8). Labels on the left indicate the sizes of the amplified fragments in bp.
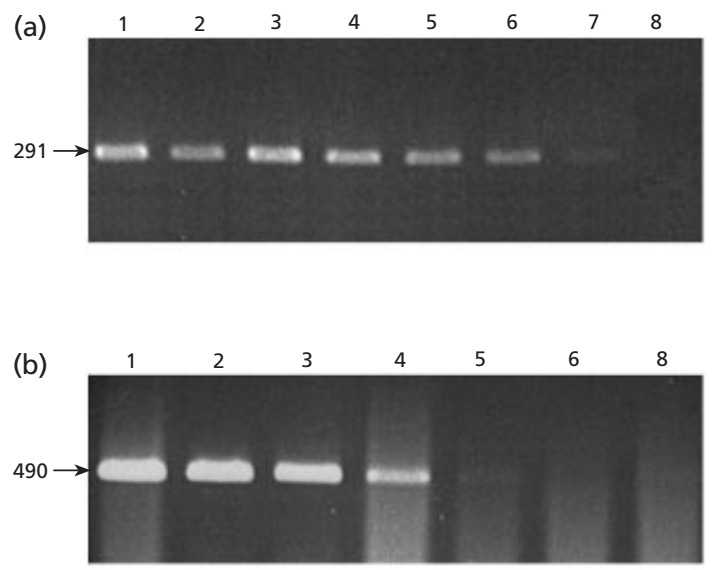

Fig. 3. Sensitivity of the RT-PCR. Reactions were carried out using the corresponding pairs of oligonucleotide primers for ygal (a) or $y g a D$ (b). Serial dilutions of a total RNA preparation from cells grown in minimal medium were used as templates for the different reactions: $500 \mathrm{ng}$ (lane 1), $250 \mathrm{ng}$ (lane 2), $100 \mathrm{ng}$ (lane 3), $50 \mathrm{ng}$ (lane 4), $10 \mathrm{ng}$ (lane 5), $5 \mathrm{ng}$ (lane 6) and $1 \mathrm{ng}$ (lane 7). In a separate reaction, $500 \mathrm{ng}$ total RNA was incubated in the absence of reverse trancriptase (lane 8 ) as a control. Labels on the left indicate the sizes of the amplified fragments in bp.

total RNA preparations were used as templates for the RT-PCR amplification of mRNAs from a gene, the transcript of which was detected by Northern blot analysis (ygaI; A. Hernández, V. Parro \& R. P. Mellado, unpublished results) and from another gene, the transcript of which was only detected by RT-PCR analysis $(y g a D)$. Fig. 3(a) shows that transcription from ygaI could be detected even when only 5 ng total RNA was used as a template, whereas $50 \mathrm{ng}$ total RNA seemed to be the minimum amount needed to clearly detect the ygaD transcript (Fig. 3b). Therefore, a 10-fold difference in the level of detection could be established between the two kinds of transcripts. Considering that a maximum of $5 \%$ of a total RNA preparation is mRNA and that the B. subtilis genome contains approximately 4000 proteinencoding genes (Kunst et al., 1997), and assuming that all genes are transcribed (at least to an extent detectable by RT-PCR) and a mean yield of about $3 \mathrm{mg}$ RNA per $\mathrm{ml}$ of culture that contains $2 \times 10^{9}$ cells, the RT-PCR detection limit appears to be approximately 0.7 (less than one) transcripts per cell. Therefore the RT-PCR approach is more sensitive than the conventional Northern blot analysis and appears to be more sensitive than the assay based on total RNA hybridization to oligonucleotide arrays (de Sazieu et al., 1997), where detection limits were reported to be around two transcripts per cell.

From the results obtained it is concluded that RT-PCR could be a useful technique for simultaneous transcriptional analysis of large regions of bacterial genomes since it is easy to use, does not require hybridization to labelled probes, is very sensitive, differentiates between expression levels, and can be used for the analysis of coordinately expressed genes.

\section{ACKNOWLEDGEMENTS}

We thank Dr Colin Harwood and Dr Zoltan Pragai for their generous gifts of some of the synthetic oligonucleotides used in this work. This research was supported by Grant BIO2-CT950278 from the European Union.

\section{REFERENCES}

Anagnostopoulos, C. \& Spizizen, J. (1961). Requirements for transformation in Bacillus subtilis. J Bacteriol 81, 741-746.

Beall, B., Driks, A., Losick, R. \& Moran, C. P., Jr (1993). Cloning and characterization of a gene required for assembly of the Bacillus subtilis spore coat. J Bacteriol 175, 1705-1716.

Chuang, S. E., Daniels, D. L. \& Blatner, F. R. (1993). Global regulation of gene expression in Escherichia coli. J Bacteriol 175, 2026-2036.

Harwood, C. R. \& Cutting, S. M. (1990). Molecular Biological Methods for Bacillus. Chichester: Wiley.

Kedzierski, W. \& Porter, J. C. (1991). A novel non-enzymatic procedure for removing DNA template from RNA transcription mixtures. Biotechniques 10, 210-214.

Kunst, F., Ogasawara, N., Moszer, I. \& 148 other authors (1997). The complete genome sequence of the gram-positive bacterium Bacillus subtilis. Nature 390, 249-256.

Lockhart, D. J., Dong, H., Byrne, M. C. \& 8 other authors (1996). Expression monitoring by hybridization to high-density oligonucleotide arrays. Nature Biotechnol 14, 1675-1680.

Mellado, R. P., Delius, H., Klein, B. \& Murray, K. (1981). 
Transcription of sea urchin histone genes in Escherichia coli. Nucleic Acids Res 9, 3889-3906.

Pascal, M., Kunst, F., Lepesant, J. A. \& Dedonder, R. (1971). Characterization of two sucrase activities in Bacillus subtilis Marburg. Biochimie 53, 1059-1066.

Pease, A. C., Solas, D., Sullivan, E. J., Cronin, M. T., Holmes, C. P. \& Fodor, S.P. (1994). Light-directed oligonucleotide arrays for rapid DNA sequence analysis. Proc Natl Acad Sci USA 91, 5022-5026.

Plum, G. \& Clark-Curtiss, J. E. (1994). Induction of Mycobacterium avium gene expression following phagocytosis by human macrophages. Infect Immun 62, 476-483.

Sá-Nogueira, I. \& Ramos, S. (1997). The Bacillus subtilis L- arabinose (ara) operon: nucleotide sequence, genetic organization and expression. Microbiology 143, 957-969.

de Sazieu, A., Certa, U., Warrington, J., Gray, C., Keck, W. \& Mous, J. (1997). Bacterial transcript imaging by hybridization of total RNA to oligonucleotide arrays. Nature Biotechnol 16, 45-48.

Schaeffer, P., Millet, J. \& Aubert, J.-P. (1965). Catabolic repression of bacterial sporulation. Proc Natl Acad Sci USA 54, 704-711.

Wodicka, L., Dong, H., Mittmann, M., Ho, M.-H. \& Lockhart, D. (1997). Genome wide expression monitoring in Saccharomyces cerevisiae. Nature Biotechnol 15, 1359-1367.

Received 29 September 1999; accepted 31 January 2000. 